\title{
DID NONVIOLENT RESISTANCE FAIL IN KOSOVO?
}

\author{
Aleksandar Marsavelski, Furtuna Sheremeti and John Braithwaite*
}

A standard narrative is that nonviolence failed in Kosovo: the Milosevic regime was ended by a NATO bombing campaign. This essay exposes errors in this narrative. Kosovo's nonviolent resistance successfully unified the masses against the regime with a distinctive innovation of building solidarity by reducing violence. In particular, it reduced murders in blood feuds. Kosovo emerged from war with comparatively low violence for a post-conflict society burdened with organized crime. We contrast Kosovo with societies where more people were killed by criminal violence after peace agreements than in wartime. Reconciling blood feuds as part of Kosovo's nonviolent campaign for freedom contributed to this accomplishment. Nonviolent resistance campaigns can be evaluated through a criminological lens whereby averting war is just one means to reducing death rates from intentional violence.

Keywords: Kosovo, blood feuds, homicide, nonviolent resistance, reconciliation

\section{Introduction}

Violent crimes by ethnic Albanians in the Balkans have been linked to an Albanian 'culture of violence' (Arsovska 2006; Arsovska and Craig 2006). We can trace the roots of certain violent practices in Albanian customary laws, such as the Code of Lekë Dukagjini (Kanun), which institutionalizes blood feuds. Criminological studies of 'cultures of violence'-explaining violent assaultive crimes by viewing them through the lens of their historical, social and cultural context from which they spring-have been present in the literature since the 1960s. These studies suggest that violence can be culturally viewed as acceptable, appropriate and even obligatory reaction to certain challenges or transgressions (Wolfgang and Ferracuti 1967; Gastil 1971; Luckenbill and Doyle 1989; Cohen and Nisbett 1994; Anderson 1999; Rich and Grey 2005; Stewart and Simons 2010). Such studies are mainly focused on the cultural causes of violence, while they devote less attention to the cultural instruments against violence. A reciprocal approach to criminology integrates the analysis of both violent and nonviolent responses to crime through dialectical concepts of adversarialism and mutualism (Barak 2005). Every 'culture of violence' contains elements of a 'culture of nonviolence', and vice versa. We can find violent and nonviolent cultural patterns in all societies, but the level of violence depends on their proportions.

Restorative justice is just one of those cultural patterns that can help build a 'culture of nonviolence'. If we want a society with less violence, restorative justice has potential to institutionalize pride and acknowledge shame that heals damaged social bonds (Retzinger and Scheff 1996; Braithwaite 2002). A restorative conception of justice is able to respond to violence by depriving it of privileged status as a strategy for ordering

\footnotetext{
*Aleksandar Marsavelski, Faculty of Law, University of Zagreb, Trg m. Tita 14, 10000 Zagreb, Croatia; Furtuna Sheremeti, Leuvens Instituut voor Criminologie (LINC), Herbert Hooverplein 9 - bus 3418, 3000 Leuven, België; John Braithwaite, Regulatory Institutions Network, College of Asia and the Pacific, Australian National University, Canberra, ACT 0200, Australia; john.braithwaite@anu.edu.au.
}

Page 1 of 19

(C) The Author 2017. Published by Oxford University Press on behalf of the Centre for Crime and Justice Studies (ISTD). All rights reserved. For permissions, please e-mail: journals.permissions@oup.com 
security (Shearing 1997: 12). Restorative traditions are rooted in nearly all cultures across the globe, as are punitive traditions. Some ancient traditions, including Arab, Greek and Roman civilizations, which left a strong impact on Kosovo's corner of the world, accepted restorative justice approaches even to homicide (Van Ness 1986: 64-8). At the same time, within these traditions, the restorative lens was frequently pushed aside or compromised by a punitive lens that has particular force in honour cultures.

Kosovo's nonviolent campaign against blood feuds is a case where a restorative justice cultural pattern succeeded in defeating a culture of violence. No claim is made about this as a universal tendency, of course. Rather our objective is to explore and understand the nature of the contest between restorative nonviolence and violent alternatives. The structure of this article is first to put our Kosovo research on crime and war in a broader context of learning lessons about taking nonviolent resistance seriously. We begin the paper with counterfactual analysis aimed at putting forward the lessons the international community might learn from the repeated errors in preventing violent conflicts such as the one in Kosovo in the 1990s and in Syria today. Then, we follow the long trajectory of the Kosovar Albanian 'culture of nonviolence', which used traditional Albanian restorative justice mechanisms to reconcile blood feuds in the early 1990s. The next sections of the article document the history of nonviolent resistance in Kosovo, including the campaign against blood feuds. That campaign reduced homicide both pre- and post-war. Furthermore, nonviolent resistance in Kosovo might have been given the chance to prevent the war, including the post-war strategic violence. But our main conclusion in the quantitative analysis that follows is that even as it failed to do so, it succeeded in reducing violence by reducing crime.

This study is part of a larger Peacebuilding Compared project that codes a number of variables about the character and strength of nonviolent resistance in countries that have experienced wars. This will permit assessment of whether our qualitative conclusion that civil resistance in Kosovo did make a contribution to violent crime reduction has wider relevance across more than 50 wars since 1990. The qualitative method primarily used in the project are interviews (and the published fieldwork of others), which enables coding of variables that are never coded in the leading quantitative research, such as the dynamics and shape of reconciliation processes, or ethnographic evidence about the impacts of certain cultural phenomena on crime rates. Most of the 48 interviews typed up for this research were conducted together by John Braithwaite and Aleksandar Marsavelski during fieldwork in Kosovo in December 2015. Two more interviews were conducted by Furtuna Sheremeti in Prishtina after the principal fieldwork finished. John Braithwaite and Aleksandar Marsavelski did three more fieldwork trips in former Yugoslavia between May 2014 and August 2016 and 11 interviews on Kosovo elsewhere between 2005 and 2016. Our ethics protocols require that all interviews be anonymous unless informants specifically request that they be on the record. The qualitative analysis is followed by quantitative analysis of statistical information about rates of intentional homicides, accidental deaths and suicides in Kosovo in the period between 1953 and 2013.

\section{Kosovo and Syria: Learning From Repeated Errors}

Kosovo in 1999 and Syria today both seem cases of failed nonviolence. When the wave of unrest spread across the Arab world in 2011, the democratic movement on the streets 
of Syria was determined in its nonviolence, more committed to resist picking up guns than in most Arab Spring uprisings. Likewise, Kosovo had an unusually vibrant nonviolent resistance to Serbian domination in the 1980s and 1990s. In both cases, when external powers opted for armed conflict-Milosevic and NATO in Kosovo; ISIS, al Qaeda, Hezbollah, the United States, Russia, Iran and more in Syria-it became maximally difficult for nonviolence to succeed. In Syria, as in Kosovo, nonviolent resistance to tyranny received limited international funding, while armed fighters against Assad won cash and recruits aplenty (as did Assad to repel them).

Hence, we consider a new frame in this article. When a country is caught in a multiplex regional acceleration of violence, it is hard for nonviolence to prevail (Braithwaite and D'Costa, in press). The nonviolent resistance of the Democratic League of Kosovo (LDK), led by Ibrahim Rugova, sought support from Croatia to resist Serbian domination. But Croatian President Franjo Tudjman, and also Bosnian President Alija Izetbegovic, pressed Kosovo to open another armed front against Serbia. Once war is on the march across a region, there will always be interests that seek to persuade a switch from nonviolent struggle against a shared enemy to a new front of their armed struggle against that enemy.

What had been needed was for the United States, the EU and Russia to work in concert to restrain leaders like Tudjman from provoking Milosevic, and then to restrain Milosevic. Interposition of NATO and Russian troops between Serbia and Croatia to prevent the first dreadful cascade toward total war in Yugoslavia was the needed intervention. Ultimately joint NATO and Russian peace enforcement deployment did happen in Kosovo, and another subsequent UN peacekeeping deployment prevented a further cascade of war from Kosovo to Macedonia. So, what seemed difficult in 1989 became an imperative from 1999. As UN and US diplomat David Phillips (2012: 348) put it: 'The UN Preventive Deployment in Macedonia (UNPREDEP) was a model for preventive diplomacy'. Had the great powers behaved differently, might nonviolence have worked in allowing a peaceful transition to separation of Kosovo and Serbia, as with the Czech and Slovak Republics, and indeed the separation of Slovenia from Yugoslavia, before total war broke out in Croatia and Bosnia? A less terrible outcome for the people of Syria likewise might have been achieved by international diplomacy to put narrowly conceived interests aside to prevent a civil war. A peaceful outcome was possible through joint NATO, Russian and regional resolve in 2011 to persuade Assad and the Free Syrian Army that the great powers stood ready to put their troops at risk as peacekeepers in order to prevent war. Such reasoning is in line with peacemaking criminology, which seeks ways of making peace instead of making war on violence (Pepinsky 1999).

Counterfactual social science has an important role to play if we hope to improve at diagnosing the lessons to be learnt from such paths not taken (Weber 1949; Lewis 1973; Climo and Howells 1976; Fearton 1991; Ferguson 2011). This essay asks a counterfactual question that intertwines with the war-prevention counterfactuals we have just discussed. Had the nonviolent resistance campaigns in Kosovo in the 1990s never been launched would Kosovo have been better or worse off? Did nonviolent resistance simply prolong the suffering of the people of Kosovo by deferring the war that was their only path to freedom? Did nonviolent resistance distract the Kosovar resistance from focusing its energy on arming and training itself for an inevitable war? 
This study answers these questions in the negative. It concludes that even though the nonviolent resistance strategy was flawed, even though western support for it was even more flawed, more lives would likely have been lost in Kosovo had the path of nonviolence not been attempted. This conclusion flies in the face of a standard narrative: that nonviolence failed in Kosovo; conversely, war worked, the NATO bombing worked, the Kosovo Liberation Army (KLA) insurgency worked.

\section{The Long Trajectory of Kosovar Albanian Nonviolence}

\section{Kanun's violent and nonviolent features}

Albanian tradition places great importance on honour, in particular on men to avenge crimes against their family. Blood feuds have been recorded that continued between two families for 80 years across 32 instances of revenge killing (Mangalakova 2004: 11). Such practices confirm the existence of an Albanian 'culture of violence' in the past (Arsovska 2006; Arsovska and Craig 2006).

The blood feuds were in line with the Code of Lekë Dukagjini, the most influential customary law of Kosovo usually referred to as Lekë's Kanun, or simply the Kanun. Lekë's Kanun is a medieval blend of tribal and Old Testament doctrines; most Kosovars did not become Muslims until quite late in the history of the Ottoman Empire. The Kanun relies on families and tribes to enforce the law rather than the state. Indeed, it specifically resists state authority in a variety of ways. In laws passed by the Banner of Kurbin under the Kanun in 1906, it was a crime to become a policeman and even a crime to offer food to a policeman or allow policemen inside one's house (Gjecov 1989: 256).

One point, however, is indisputable: for the clans of Northern Albania, the maxims of the Kanun were primary, i.e. they took precedence over all other laws, and for that reason both the church and the state opposed the application of the Kanun ... There is no doubt that [the Kanun is] the fundamental customary law employed in the Middle Ages in almost all of the areas of Albanian settlement (Camaj 1989: xiii).

Honour (nderi) is just one of the four pillars of the Kanun, the others being hospitality (mikpritja), right conduct (sjellja) and loyalty to one's clan ( fis). The Kanun institutionalizes blood feuds by obliging killing a member of a family that has offended against your family.

At the same time, the Kanun promotes a 'culture of nonviolence' by institutionalizing reconciliation and control of violence through many restorative institutions like the besa-meaning generally a vow (Marsavelski et al. 2016). Besa that no one would hurt a murderer during a reconciliation process are particularly important. As Suzanna Pratt (2013: 1) put it, 'the same social code justifying blood feuds also contains the foundations of a restorative justice process ... The restorative features of traditional mediation have the potential to lead to widespread reconciliation of blood feuds and alleviation of continued cyclical violence in northern Albania'.

In Kosovo today, a common view among legal and legislative elites is that independent Kosovo courts render the Kanun redundant or of diminished importance. Most commentators conceive the influence of the Kanun in the 21st century as greater in rural areas, though many commentators note significant continuity of urban influence, 
as in Voell's (2003) ethnographic work showing the Kanun to exist as 'habitus' in suburban Tirana, the capital of Albania.

\section{History of late 20th century nonviolent resistance}

Year 1968 was a watershed year of bottom-up resistance to oppression around the world, including in Kosovo. Protestors marched the streets of Prishtina on 27 November objecting to the 'colonial' oppression of Kosovo, chanting 'We want a university'. The police crushed it brutally, though only one demonstrator was killed. The next wave of protests started in March 1981 at the University of Prishtina, which had been established by then. Perhaps even 1,000 (Malcolm 1998: 335) of the protestors were killed. Year 1988 saw huge protests again after Milosevic started moves to dismantle Kosovo's autonomy within Yugoslavia. Trepça miners went on strike and marched to Prishtina to be joined by factory workers and students-100,000 in total. Throughout Kosovo perhaps 300,000 joined multiple marches (Clark 2000: 48). The confrontation escalated in February 1989, when 1,200 miners locked themselves deep in shafts to disrupt production. At this point, the nonviolent resistance was proactive, creative and imposing real political and economic costs on Milosevic, forcing him to make political concessions to the miners, on which he subsequently reneged.

The political cost of Milosevic's 1989 revocation of the autonomy of Kosovo was enormous: this was the domino that caused the rest to fall and disintegrate Yugoslavia. In September 1990, Kosovo held an independence referendum and in 1992 Kosovowide elections elected a parallel government. Ibrahim Rugova was elected after he was approached by the leadership of the nonviolent resistance to become the head of the Democratic League of Kosovo (LDK). Rugova continued the execution of nonviolent principles. Whenever a demonstration occurred, LDK operatives would be on the street urging nonviolent discipline upon the protestors so as not to provoke state violence.

Rugova's leadership, however, failed to respond to dissatisfaction of the democracy movement, particularly the students, that the resistance strategy was too passive and losing the momentum it enjoyed between 1988 and 1992. The students were right in this critique. Convening the parliament in the presence of the international media as a venue for condemnation of the regime and for robust open debate on strategy would have posed a difficult dilemma for Milosevic. He would have had to bear the political costs of allowing the parliament to condemn his regime, or the awful international optics of forcibly closing the parallel democratic chamber.

It suited Milosevic to keep Rugova alive and out of prison because he was pacifying the nonviolent resistance. Western diplomats tacitly supported the status quo as they did not want to spook Milosevic from signing the Dayton Accord to secure peace in Bosnia. Even some members of Rugova's inner circle agreed, when we interviewed them, that Rugova allowed himself to be overly influenced by western diplomats to keep the resistance passive. For example, he sought to dissuade the students from organizing street protests because this would provoke state violence. In addition, all major political movements in Kosovo failed to hedge with the option of working with the nonviolent resistance to destabilize Milosevic inside Serbia. In East Timor at the same time, Fretilin was assuming a major leadership role in Jakarta in the nonviolent democracy movement to overthrow Indonesia's Suharto (Braithwaite et al. 2012). There was only a tiny minority 
of Kosovo leaders, notably women, who advocated enhanced contacts with the Serbian opposition when hundreds of thousands of Serbs surged onto the streets of Belgrade to challenge Milosevic (Stephan 2006: 74).

As a result of these errors, the nonviolent strategy ceased inflicting significant economic, political or diplomatic costs on the Milosevic regime. When Rugova and Kosovo were excluded from discussions at Dayton, popular frustration with the tame character of Rugova's resistance and feelings of hatred toward the Serbian regime passed a tipping point. The armed resistance of the KLA was the main alternative that quickly built mass support in Kosovo after Dayton.

According to Barak (2005: 142), group hatred can potentially result in violence, which he considers a way of opposing the other (adversarialism), as well as of enjoying solidarity with similarly inclined people (mutualism). Kosovo Albanians first developed mutual responses to violence and tyranny by reconciling blood feuds and engaging in nonviolent resistance. But mutualism manifests also in group love as an expression of solidarity with others, including one's enemies (Barak 2005: 142). Kosovo Albanians failed to include their fellow Serbs in Kosovo in the campaign against Milosevic's regime. Then this and other failures of Rugova's strategy and international diplomacy resulted in adversarial responses through armed resistance against the oppressor.

\section{Resisting oppression: the largest restorative justice process reconciling blood feuds}

In Communist Yugoslavia, the Kanun was banned and suppressed, as it was in Communist Albania. Yet it survived as a form of resistance. According to some commentators, the influence of the Kanun increased after the fall of communism (Pratt 2013: 4). The Kanun was in part an institution for reconciling feuds within Albanian society to unify resistance to Ottoman rule. At a number of notable points in the centuries of resistance to 'the Turks', there were concerted campaigns across the northern Albanian lands to invoke the Kanun to reconcile all internal blood feuds before launching a new surge of Albanian resistance. The last of these massive society-wide reconciliation campaigns under Ottoman domination were in 1910 (10 April; 1 May), with earlier campaigns including 1878, 1703 and 1444 (Clark 2000: 64).

In 1990, a group of Albanian university students decided to revive this tradition. Scholar Anton Cetta joined them to become the public face of their campaign, as did many leaders of the Council for the Defense of Human Rights and Freedoms. It was initially called Action for Blood Feud Reconciliation. Approximately 500 activists crisscrossed Kosovo between 1990 and 1992 in a scaled-up reconciliation movement to end blood feuds. The students visited house-to-house to persuade Albanians that if they were to unite against the threat posed by Milosevic, they would have to resolve their blood feuds first. Estimates vary as to the number of blood feuds reconciled in this campaign, with the Mangalakova (2004) estimate for the International Centre for Minority Studies and Intercultural Relations of 1,200 often cited, though Clark (2001) estimated 2,000 ceremonies of reconciliation completion, and Luci (2014: 68, 101) 2,000-2,500. The campaign was described by one who attended as a contagion of reconciliation: 'Someone forgiving the blood turned into an act of others to follow' (Prishtina interview 121525). This informant described Çetta's method as looking for promising cases where reconciliation could be achieved and then using those as virtuous examples to create a cascade of further reconciliations. 
The numbers in the last paragraph do not capture the magnitude of what happened. They do not count the number who attended each reconciliation. That number ranged from hundreds to thousands for each final gathering. According to one informant who worked on the campaign, it was common for there to be a considerable number of working meetings toward reconciliation that would be attended by an average of 30 people. Then there would often be more than a thousand people, dignitaries, food, dance and folkloric music at the final ritual of reconciliation. The largest was the reconciliation gathering at Verrat e Llukës on 1 May 1990 where even the official Tanjug Agency reported 100,000 participants, while Çetta himself estimated 500,000 (Clark 2000: 63). Parts of this event can be viewed at: https://www.youtube.com/watch?v=Braqs43CnmU. Luci (2014: 101) concludes 'Over a period of two years, more than 500,000 people were said to or were documented to have taken part in mass organized meetings of reconciliation'. Ethnographer Bekim Xhemili reckoned 500,000 attended the 1 May 1990 final gathering for reconciliation, and that blood feuds mostly died out with the decisive point being the nonviolent campaign (Prishtina interview 121501). There may not be any other reconciliation or restorative justice process in recent decades that can claim this level of mass participation, of the order of a third of the total population of a society in a short space of time.

The female students of the campaign joined hands with local women to evoke a limited but meaningful feminist transformation of tradition through the campaign. As Luci (2014: 119) put it:

In many ways, the reconciliation movement was characterized by the refashioning of previous 'male domains' in the public sphere of homes, which required specific forms of speech and narrative forms, into more inclusive spaces where women became agents in a new, even though temporary, vision of resistance. Serbian nationalist discourse and public imagery had constructed an idea of a backward Albanian culture, a violent masculinity, and thus dominated femininity. Therefore, a politics of culture emerged in Kosova, which sought not only to dispel such imaginings, but foremost to show that Albanian cultural traditions could animate emancipatory politics (Luci 2014: 246).

After the war, the unifying motivation of resisting tyranny that was present in the campaign against blood feuds during the 1990s was missing. It took years before NGOs became strong enough to begin to make blood feud reconciliation work a priority. The Committee for Nationwide Reconciliation, the Albanian Foundation for Conflict Resolution and Reconciliation of Disputes, Partners Kosova and the Peace Missionaries Union have done important work in reconciling blood feuds but have not had the human resources to tackle a growing backlog of unaddressed feuds. The post-war struggle for international recognition of Kosovo's independence hindered the use of the Kanun's guest-friendly provisions for a political narrative that would prevent violence against Serbs and their exodus from Kosovo (Marsavelski et al. 2016).

\section{Impacts of the Campaign on Reduction of Violent Crime}

No one would claim that blood feuds were completely eliminated, but most commentators believe most extant blood feuds were resolved as a result of the campaign. Some scholars even comment that 'virtually no blood feuds continued' (Clark 2001: 2). It became an act of disloyalty against the resistance to pursue a blood feud against fellow 
Albanians in Kosovo. Aggrieved families 'pardoned the blood ... in the name of the youth, the people and the flag' (Clark 2001: 2), language often repeated in our interviews. For many of the youth, this was also part of a more general move away from patriarchal traditions and toward becoming modern Europeans, while at the same time embracing the reconciliatory traditions of the Kanun. This changed cultural habits, perhaps even permanently to some degree.

After the war, however, when the patriotic obligation to avert blood feuds ended, new feuds did spring up, including some caused by killing during the war and by testimony against defendants in war crime trials. These surged back to a significant degree between 2000 and 2004, though many of the murders of this period undoubtedly harnessed the blood feud narrative to what was strategic political murder. Then murders pursuant to blood feuds almost certainly fell again in the 12 years since 2004 once the initial surge of post-war revenge violence settled. Some reestablishment of the culture of nonviolence is indicated by Arsovska and Verduyn's (2008: 235) cross-national survey, according to which Kosovar Albanians support violence least among ethnic Albanian respondents from Albania, Kosovo and Macedonia.

The Council for the Defence of Human Rights and Freedoms reported data from the end of the war until 2003 on about 40 murders related to blood feuds recorded in Kosovo (Mangalakova 2004: 11), though there were undoubtedly other unreported cases. Partners Kosova in our interview and in other forums see the incidence of blood feuds as lower than this today. Before 1990, there is no systematic recording of blood feud killings in Kosovo, though the New York Times quoted Pristina's Institute for Albanian Studies as estimating as many as 100 murders in single years during the 1980s (Sudetic 1990). This seems an implausibly high claim to the Kosovar experts, statisticians and scholars we interviewed. In 1989, the year before the campaign started, Clark (2000: 61) reports only 15 deaths from blood feuds. This is still a larger number than the average of 10 a year in the years immediately after the war and a much larger number than has been reported for any single year since.

Boyle (2014) characterizes Kosovo as a society that suffered a high level of strategic violence in its first five years of 'peace'. Strategic violence is defined as violence aimed at transforming the balance of power and resources in a contested area. While Bosnia suffered a much more deadly war than Kosovo, it was Kosovo that suffered the more deadly post-conflict strategic violence. Boyle (2014: Chapter 6) found Bosnia, with twice the population of Kosovo, to suffer only 42 cases of post-conflict strategic violence, while Kosovo had 213 in a comparable five-year period, largely as a result of attacks against Serb, Roma and other minorities. Mostly this amounted to threats of violence, burning of houses, sniper fire to terrify populations to flee, grenade attacks, etc. There was also extensive factional violence between rival Albanian groups. One former member of the KLA/PDK intelligence organization, SHIK, Nazim Bllaca, has confessed to multiple murders himself and alleged that SHIK killed 450 people in the decade after the war, mostly by 2004, mostly political opponents of PDK, particularly members of LDK. Leaked reports of the EU's rule of law mission, EULEX, and German intelligence, support the analysis that PDK directed a campaign of political assassinations and kidnappings against its opponents (Boyle 2014: Chapter 6). While strategic political violence in Kosovo with 213 killings in the five-year post-conflict period was much worse than Bosnia, it was not as bad as Iraq $(82,682)$, Rwanda $(8,439)$ or East Timor (322). 
Moving beyond strategic political violence to the general level of violence, Boyle 2014: Table 6.3) compared the level of violent crime in the first year after the war with Northern Ireland, which also terminated its conflict at the end of the 1990s and has a slightly higher population than Kosovo. Kosovo had 245 murders in 2000, while Northern Ireland had only 44. On the positive side Kosovo had half the recorded rapes (115) of Northern Ireland (232) though in both jurisdictions there was hesitation of women to report rape cases.

There are many reasons why criminologists would predict a high homicide rate in Kosovo. It is a society in which a patriarchal honour code is still part of the habitus of the people (Färnsveden et al. 2014: 16), a characteristic of many countries with the highest homicide rates, such as El Salvador, Guatemala, Honduras, Venezuela and Colombia. In turn, the honour code helps sustain a formidable male gang and organized crime culture which can stake a competitive advantage in trafficking in drugs, humans or guns. In Kosovo, organized crime grew after the mass dismissal of Albanians from the legitimate economy in 1989, causing many to turn to the illegitimate economy and the violence so often associated with it. In 2004, UNMIK estimated that 80 per cent of the heroin destined for Western European markets passed through Kosovo or Macedonia. In 2008, UNMIK estimated the share of entrenched organized crime in Kosovo's economy at 15-20 per cent (Proksik 2013: 284). The International Organization for Migration estimated that approximately 200,000 women annually in this period were stripped of their identity papers and bought and sold by Balkan sex cartels and their extensions (Giatzidis 2007: 328).

Kosovo is a post-war society; participation in a war increases post-war homicide (Archer and Gartner 1984; Ghobarah et al. 2003). After its peace agreement was signed in the 1990s, the homicide rate in El Salvador spiked to 135 per 100,000, a huge contrast to Kosovo's single digit rate. More people were being killed by homicide after El Salvador's successful peace agreement was signed than were being killed during the worst years of its war (Geneva Declaration 2011: Chapter 2). We have seen similar scenarios in Iraq (Boyle 2014: Chapter 8) and a number of African and other wars (Duffield 2001: 188). Widespread disruption of settled institutions by refugee flows contributes to post-war violence (Braithwaite and D'Costa, in press: Chapter 3) and Kosovo had a much larger scale of refugee suffering compared to countries that suffered bigger, longer wars. By 2000, 90 per cent of the population of Kosovo had been driven from their homes, the majority of them being Albanians (Naimark 2002: 182) who were driven out first, followed by Serbs (and Roma) in a reverse cleansing. Kosovo inherited a gun culture that was worsened by an avalanche of weapons flowing in from Albania during the war. Sixty-five per cent of households continued to own at least one firearm after years of UN and EU effort to destroy weapons (Pozhidaev and Andzhelich 2005: 63). Kosovo is a post-Communist society and such societies tended to suffer steep increases in homicide after the collapse of Communism (Karstedt 2006). 'The fall of the communist regimes prompted the virtual collapse of the states' control functions' (Giatzidis 2007: 328), especially so in Kosovo after 1989 when Kosovo Albanians withdrew all cooperation with what limited state functionality was left. Karstedt (2006: 55) concludes that increased homicide rates following transitions to democracy usually involve anomic tendencies that persist through quite a long duration of transition. We saw extremely elevated homicide rates for many years in most post-communist transitions, and in South Africa, for example. 
Kosovo has a youth bulge, a 40 per cent unemployment rate and is the poorest society with possibly still the weakest state in Europe. There can be no dispute that it started this century as the weakest state in Europe because in 2000 it had no well-established state institutions. All the factors discussed in the last paragraphs mean that Kosovo is a most likely case (Eckstein 1975) for a high homicide rate. Corruption, organized crime that implemented widespread assassinations, outlier levels of drug and other trafficking, extremely high gun ownership, the honour culture, revenge culture, being a postwar, post-authoritarian society with a weak state, having 90 per cent of the population refugees, a youth bulge and high unemployment all would lead us to expect an above average homicide rate in post-war Kosovo. In the next section, however, we ponder a Kosovo homicide rate in recent years at one-third the world average homicide rate per 100,000 adults (6.2 according to UNODC). Counterfactual analysts are attracted to cases like these to move from quantitative analysis to a qualitative search for particular historical conjunctures associated with changes to homicide patterns. This is the analysis undertaken in the next section.

\section{Historical Trends in Kosovo Homicide Rates}

\section{Data sources}

Homicide rates herein are based on data on intentional homicides collected from: (1) Official Country Statistics for the period between 1953 and 2013; (2) Ismet Salihu's (1982) Dissertation for the period between 1957 and 1977; (3) Kosovo Police for the period between 1999 and 2013; (4) UNMIK Police for the period between 2000 and 2005; (5) UNODC (2016) and World Bank (2016) for the period between 2008 and 2013. As presented in Figure 1, there are discrepancies between different sources due to different data collection methods; however, they converge on a common pattern. Our research also delved qualitatively into the data, e.g. through interviews with Sanije Uka from the Agency of Statistics in Kosovo who has remained behind the data presented here since 1990 (sources 1 and 3) and Professor Ismet Salihu (source 2). Salihu's qualitative work revealed many cases in the last century where the Serbian police had not reported correctly, e.g. by substituting homicide with suicide on many occasions. This critical qualitative individualization of the data gives reason for suspecting an even sharper comparative reduction in the homicide rate since the Kosovo war compared to the period of Serbian domination of the justice system.

Official Country Statistics cover the longest period measuring homicides in Kosovo. They are based on data collected by civil registry offices, usually based on death certificates issued by physicians, ${ }^{1}$ and reported in the Official Country Statistics since 1953. Due to historical changes of the status of Kosovo, three different states collected the data throughout the six decades: Yugoslavia 1953-90 (SAP Kosovo 1976: 44; 1981: 47; 1985: 41; 1989: 41; SR Jugoslavija 1992: 90, 229), Serbia 1991-97 (Republički zavod za statistiku Srbije 2007: 142) and Kosovo 2002-13 (Republika e Kosovës 2015: 62). The four-year disruption in the data (1998-2001) is due to the Kosovo War and its

\footnotetext{
${ }^{1}$ In other cases, the information about the cause of death can be provided by the family of the deceased as revealed in a court decision (in case of a missing person) or based on a police report (e.g. when a missing person's corpse was found).
} 


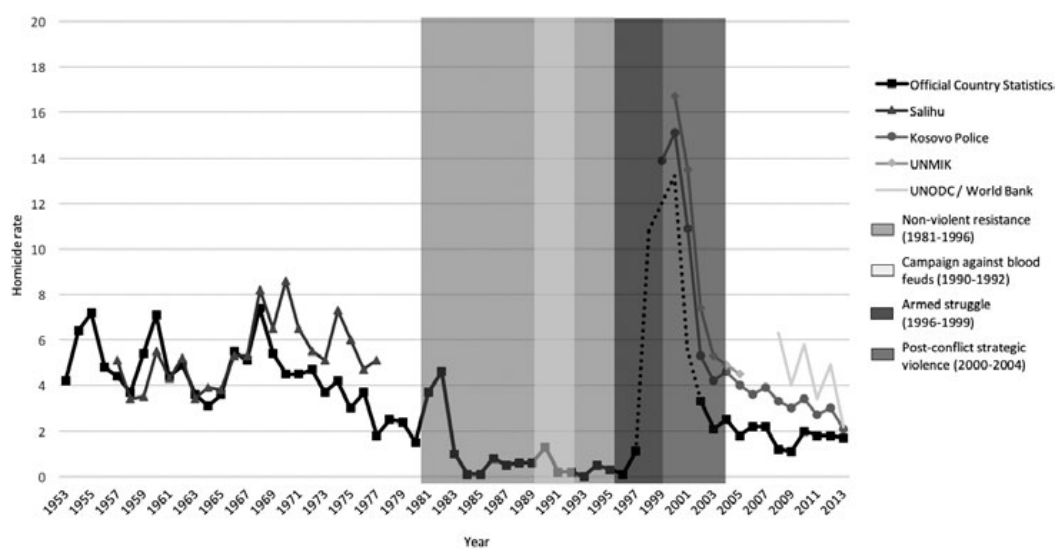

Fig. 1 Homicide rates in Kosovo in the period between 1953 and 2013.

aftermath. Dotted lines are used to project homicide rates in the period of data disruption, knowing that the homicide increased very sharply in the course of the war and post-war violence, as is also demonstrated by the Kosovo Police data.

Salihu (1982) used several sources combined to measure homicides in Kosovo: statistical reports, Salihu's own inquiry into court files on homicides that took place in the period 1966-75, reports from public prosecutors and police, as well as data cited in the literature.

The Kosovo Police data for the period between 1999 and 2013 were obtained directly from the Information Office of Kosovo Police in March 2016. UNMIK Police Data for the period between 2000 and 2005 was reported in a survey published by the South Eastern and Eastern Europe Clearinghouse for the Control of Small Arms and Light Weapons (SEESAC 2006).

The most recent UNODC (2016) and World Bank (2016) data on homicides for the period 2008-13 correspond to those reported by EUROSTAT (2016); however, EUROSTAT's homicide rates are lower due to discrepancies in population estimates for Kosovo. The fact that there has not been an accurate population census in Kosovo for decades poses a particular problem in determining homicide rates (Marsavelski et al. 2016).

\section{The homicide patterns}

Historians of Kosovo identify the 25-year history of nonviolent struggle against Belgrade's domination as starting in 1981. Even though there was an important eruption of resistance in 1968, sustained, resilient resistance did not start until 1981. Figure 1 shows that while the first year of the concerted campaign of nonviolent resistance, 1981, was a year of comparatively high homicide rates, that rate fell sharply ${ }^{2}$ and then gradually to be at extremely low levels during the 15 years of nonviolent resistance (up to 1996). Then homicide spiked to very high levels during the armed struggle, but also experienced the largest homicide drop in the aftermath of the Kosovo War. The drop has been described as the steepest decline in homicide in Kosovo's history

\footnotetext{
${ }^{2}$ Professor Salihu's more qualitative analysis in our interview with him reached the same conclusion for the 1980 s fall.
} 
(Alvazzi del Frate and Mugellini 2012: 145). The homicide levels remained moderately high, however, in the years of strategic violence immediately post-conflict (up to 2004). The picture is of gradual decline since then to the point where, by 2013, Kosovo had become a low-homicide society with the rate falling to 2 per 100,000 inhabitants; onethird of the world average of 6.2, yet still twice the homicide rate that averaged less than 1 before the conflict, between 1984 and 1996. In 2014, the homicide rate seems likely to have fallen further. Our sources within Kosovo Police state that the number of murders in Kosovo in 2014 was 35 cases, whereas in 2015 this number has dropped to 25 (a 29\% further fall).

The final important point to note is that during the long period of very low homicide during the nonviolence era, the stepping up of the nonviolence campaign between 1990 and 1992 through the campaign against blood feuds knocked the homicide rate sharply lower still during those three years, when it is closer to zero than to 1 . Indeed it remained so until the war began. After 1996 homicide escalated sharply until it reached levels that could no longer be counted in a meaningful way, though the Kosovo police counts peak at 15 per 100,000. We presume this count excludes huge numbers of murders by the police themselves and large numbers of murders classified as suicides or accidents. Most state and KLA assassinations of people were not counted until the UN administration arrived.

The Kosovo Peacebuilding literature is consistent with the international literature in generating a great deal of qualitative evidence of outbreaks of domestic violence after the war in Kosovo (Farnsworth 2008: 21), though systematic comparative survey research evidence is absent for Kosovo.

While the cross-national evidence is clear that wars increase national homicide rates post-conflict, it is equally clear that wars elevate suicide rates post-conflict (Ghoborah et al. 2003). In addition, we know that certain societies with exceptionally low homicide rates also have suicide rates ten to 20 times higher than their homicide rate-leading instances of this exceptionalism being Japan, Korea, Slovenia and Slovakia (comparisons based on UNODC homicide data and WHO suicide data). This has given birth to a longstanding Durkheimian criminological literature on whether the control of violence in low homicide rate societies can be displaced into high suicide rates (Henry and Short 1954; Gold 1958; Quinney 1965; Lester 1996; Bills and Li 2005). Our purpose here is not to resolve those debates. It simply seems important in a post-war analysis to check out the possibility that unusually low homicide rates in Kosovo are not displaced into massive internalization of violence as self-harm.

Figure 2 shows this is not the case. In comparative terms, the impact of the Kosovo war on post-war suicide rates is extremely slight. Kosovo has become a low-homicide, low-suicide society. Of great interest is the fact that Kosovo has an exceptionally low suicide rate during the years of the nonviolent resistance up to 1996. Moreover, the 1990-92 campaign against blood feuds does not displace homicide to suicide. On the contrary, 1991-93 had the lowest recorded suicide rates in modern Kosovo history. Sometimes administrations willfully conceal the truth or negligently record suicides or homicides as accidental deaths. Figure 2 shows that these also plunge to their historic low during the campaign against blood feuds and fall quite sharply during most of the years of nonviolent resistance. The massive magnitude of the decline in accidental deaths in 1991 has caused commentators to query whether blood feud deaths had been 


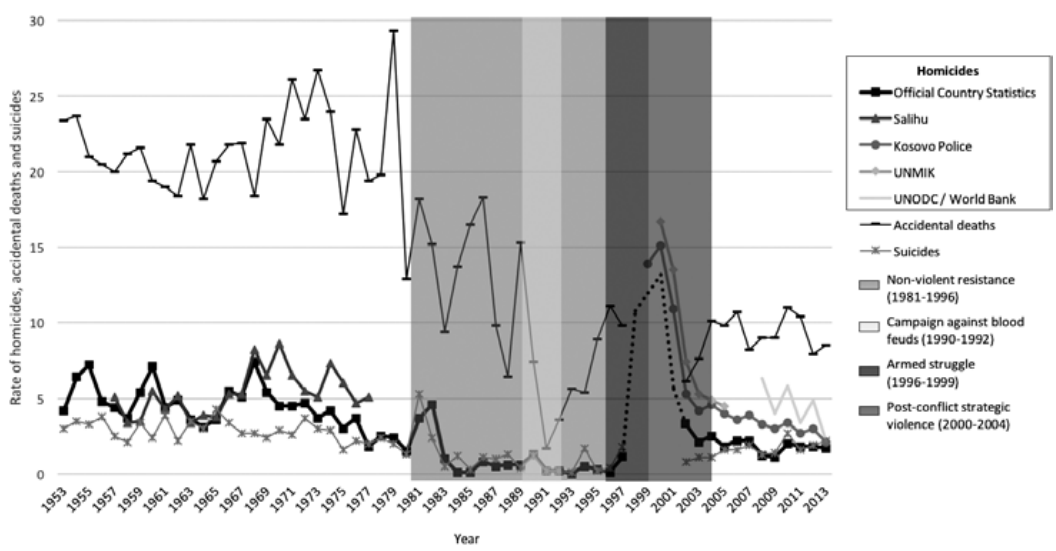

Fig. 2 Rates of intentional homicides, accidental deaths and suicides in Kosovo in the period between 1953 and 2013.

hiding inside the accidental death statistics until the campaign against blood feuds brought them to an end, even if only temporarily. ${ }^{3}$

Kosovo is a case study of applying the criminological lens to struggles against tyranny. Looking through a criminological lens, we evaluate nonviolent campaigns of resistance not only according to whether they prevent war. Rather, the criminologist evaluates them according to whether they reduce violent death, where war death is just one form of intentional killing. On the war-prevention test, nonviolent resistance in Kosovo failed. On the criminological test, it succeeded.

\section{Discussion and Conclusion}

Scholars from NATO countries tend to buy the narrative that the prolonged NATO bombing of Serbia was a necessary evil. Modern wars degenerate via the common practice of killing civilians as 'collateral' (Cohen 2001; Shaw 2015). In such circumstances, it is fairly easy to get caught up in the dynamic of another war to stop violence as the only solution (Shaw 2015: 4). War in Kosovo, including NATO bombing, was an example of a 'degenerate war' that could be said to have helped produce the 'liberation' of Kosovo, but at the price of 10,000 Albanian deaths, destruction of homes, villages and towns, and ultimately counter-violence against Serb civilians (Shaw 2015: 209). Military interventions against oppressive regimes ought to be applied only as a last resort-in those rare cases when really nothing else works-and not as an excuse for poor diplomacy that fails to head off oppression before it consolidates. Thus, conflict management in societies burdened with violence can be focused on nonviolent resistance, restorative justice and prevention of cascades of violence in preference to oppressing the oppressor.

Academic debates about the various NATO bombing campaigns mainly focus on whether they were a breach of international law. Were they justified crimes of aggression? This of course was not the debate in non-NATO countries, particularly China.

\footnotetext{
${ }^{3}$ These Kosovo data are in line with Holinger's studies showing that national rates for suicide, homicide and accidental deaths tend to be parallel over time (Holinger and Klemen 1982; Holinger et al. 1987).
} 
It saw the loss of life when its embassy in Belgrade was bombed as a crime of aggression by NATO. In this section, we use our field research in Kosovo to make the point that, viewed through the wider criminological lens we have adopted, the NATO bombing as necessary evil appears a myopic analysis.

\section{Revisionist narrative 1: had NATO supported Kosovar nonviolence, it might have succeeded}

The negotiators at Dayton excluded Rugova and his team because their struggle was not deploying violence to unsettle stability. As a result, the people of Kosovo turned against Rugova's strategy. When the KLA transformed the resistance into an armed struggle, the west took notice. Indeed, the west saw an opportunity to remove and indict Milosevic for war crimes in Kosovo. The United States provided cash to the KLA and training in violence, instead of providing training in more effective techniques of nonviolent resistance. Worse still, western diplomacy punished most the more effective forms of nonviolence. Our theory would be that in these ways, western policy created a moral hazard of armed violence. This means that the hazard of violence is increased because there are international rewards for opting for violence and international punishments for opting for nonviolent resistance. Western diplomacy shunned the proactive nonviolence of the students and the miners that was succeeding in inflicting real costs on the regime and was succeeding in discouraging Serbs from following the pressure from Milosevic's regime to settle in Kosovo.

Kosovo's nonviolence met many of Chenoweth and Stephan's (2011) conditions for the success of nonviolent resistance, particularly in mass participation, Albanian defection from the security services, and in sheer creativity and energy. It can be argued that had the west supported that nonviolence instead of threatening withdrawal of western support as soon as the nonviolent campaign got sufficiently robust to impose political costs on Milosevic, nonviolent resistance may have succeeded politically during the mid-1990s in both Kosovo and Belgrade.

\section{Revisionist narrative 2: reducing violence is the ultimate aim of nonviolence, not preventing} war; Kosovo succeeded in reducing violence

In spite of the timidity of western support, nonviolence did succeed in achieving the ultimate aim of nonviolent strategy-resisting domination by means that reduce the amount of violence in the world. This even though it failed to avert war. Reviving Albanian reconciliation skills and traditions not only opened the door to more peaceful and effective conflict resolution in the long term; in the short term (by 1992) it ended at least 1,200 deadly blood feuds each of which risked multiple murders. A theoretical account of how this was accomplished is embedded in the customary justice theory of reconciliation in the Kanun, and in restorative justice theory (Braithwaite 2002). In the long run history of almost every society during the past half century, homicide kills many more people than war and terrorism. A limitation of the nonviolence literature is that it puts all the emphasis on preventing, healing and ending war to the neglect of the commonly recurrent forms of violence such as gender-based violence, male revenge violence and strategic post-conflict violence (Boyle 2014), which are at the same time associated with war and independent of it. Restorative justice theory does not commit 
that theoretical error (Braithwaite 2002), and recently this has become true of wider criminology informed by a criminology of war developed, among others, by leading figures of the discipline (Karstedt 2012; Hagan et al. 2015; Walklate and MacGarry 2015; Rafter 2016).

\section{A balanced narrative: the mixed legacy of reconciliation and forgiveness in Kosovo and Serbia}

While our limited data triangulates on efficacy, we cannot be certain that there were long-term benefits of the campaign against blood feuds as one key plank of civil resistance in Kosovo. The qualitative data allows us to be rather certain that there were large short-term benefits. And we can be certain that the dominant western narrative that NATO bombing did all the decisive work of ending violence in Kosovo is false.

A balanced narrative is clear about the short-term benefits of nonviolent resistance in immediately reducing violence associated with blood feuds and in building mass social solidarity to resist tyranny on a wide front. It also sees some profound tactical errors in Rugova's nonviolent strategy. In the aftermath of the errors of domestic and international leaders, the rise of the KLA and the NATO bombing did play the critical final role in ending the Milosevic regime's domination of Kosovo in the bloody finale of this historical drama. In the aftermath of the Kosovo war, the preventive UN peacekeeping deployment and negotiated peace in Macedonia points, however, to a better path that might have been taken in Kosovo, in Bosnia, in Croatia had they only been taken early enough (Braithwaite and D'Costa, in press: Part I).

Our data analysis is sufficient to show that a good hypothesis is that the extraordinary breadth of the engagement of Kosovo civil society with nonviolence between 1968 and 1996, especially between 1981 and 1996, and more especially between 1990 and 1992, helped leave a legacy of a comparatively low violence post-conflict society. Kosovo is a case where violent death declines after war, in sharp contrast to the common scenario of intentional killing and suicide increases after a peace agreement is signed. The large reduction in violent death is associated with decades of nonviolent resistance, with the campaign against blood feuds being its most important period. Its key event was the reconciliation gathering of 1 May 1990, a massive restorative justice meeting with participation of an unprecedented number of people in a short space of time. The whole campaign against blood feuds resulted in homicide rates sinking to zero in 1993 according to the Official Country Statistics. In our analysis, the campaign was a restorative element of the culture of nonviolence that succeeded in sharply reducing violent death rates within the era of nonviolent resistance. Ethnographic and quantitative evidence converge on the likelihood that the campaign against blood feuds sharply reduced blood feud murders during the early 1990s. Moreover, the data suggest that blood feud murders have never returned to the levels that prevailed before 1990 .

While the various components of the nonviolent campaign against the Milosevic regime failed to prevent war, they did almost certainly prevent violence in a historically transformative way. This in a post-authoritarian, post-war society that suffered much higher immediate post-conflict strategic assassination than in other recent European conflicts such as Bosnia and Northern Ireland and in one of the worst examples of postwar capture of state and society by a murderous organized crime network. Contrary to the standard narrative that NATO bombing did all the decisive work of ending violence 
in Kosovo, this study reveals that more lives would likely have been saved had the path of nonviolence received greater support from the international community.

The results of this study in Kosovo have wider implications for criminological research than merely being a case of a restorative justice approach to nonviolence producing some benefits. It is also an example in which criminological theories of peacemaking, cultures of violence, as well as a reciprocal theory of mutualism and adversarialism converge on the idea of using nonviolent solidarity against violence. An interim test of the impact of nonviolent resistance on violent crime cross-nationally, however, will be possible at the completion of the Peacebuilding Compared data collection of which this research is a part. Thirty-eight wars beyond Kosovo have preliminary coding so far. Quantitatively, we will be able to test whether post-war homicide rates are lower when there is a history of vibrant nonviolent resistance. Qualitatively, we will be able to explore a diversity of cases for differences and similarities with Kosovo. We hope this article shows why this is comparative macrocriminological research that matters.

\section{Funding}

This research was funded by the Australian Research Council.

\section{REFERENCES}

Anderson, E. (1999), Code of the Street: Decency, Violence, and the Moral Life of the Inner City. W.W. Norton.

Alvazzi del Frate, A. and Mugellini, G. (2012), 'The Crime Drop in Non-Western Countries: A Review of Homicide Data', in J. Van Dijk, A. Tseloni and G. Farrell, eds, The International Crime Drop: New Directions in Research, 134-59. Palgrave Macmillan.

Archer, D. and Gartner, R. (1984), Violence and Crime in Cross-National Perspective. Yale University Press.

Arsovska, J. (2006), 'Understanding a "Culture of Violence and Crime”: the Kanun of Lek Dukagjini and the Rise of the Albanian Sexual-Slavery Rackets', European Journal of Crime, Criminal Law and Criminal Justice, 14: 161-84.

Arsovska, J. and Craig, M. (2006), “Honourable” Behaviour and the Conceptualisation of Violence in Ethnic-Based Organised Crime Groups: An Examination of the Albanian Kanun and the Code of the Chinese Triads', Global Crime, 7: 214-46.

Arsovska, J. and Verduyn, P. (2008), 'Globalization, Conduct Norms and "Culture Conflict": Perceptions of Violence and Crime in an Ethnic Albanian Context', The British Journal of Criminology, 48: 226-46.

BARAK, G. (2005), 'A Reciprocal Approach to Peacemaking Criminology between Adversarialism and Mutualism', Theoretical Criminology, 9: 131-52.

Bills, C. B. and Li, G. (2005), 'Correlating Homicide and Suicide', International Journal of Epidemiology, 34: 837-45.

Boyle, M. J. (2014), Violence after War: Explaining Instability in Post-Conflict States. John Hopkins University Press.

Braithwaite, J. (2002), Restorative Justice and Responsive Regulation. Oxford University Press.

Braithwaite, J., Charlesworth, H. and Soares, A. (2012), Networked Governance of Freedom and Tyranny. Australian National University Press. 
Braithwaite, J. and D’Costa, B. (In press), Cascades of Violence. Australian National University Press.

Camaj, M. (1989), 'Foreword', in S. Gjecov, ed., The Code of Lekë Dukagjini. Trans. Leonard Fox, xiii-xv. Gjonlekaj Publishing Company.

Chenoweth, E. and Stephan, M. J. (2011), Why Civil Resistance Works: The Strategic Logic of Nonviolent Conflict. Columbia University Press.

Clark, H. (2000), Civil Resistance in Kosovo. Pluto Press.

Clark, H. (2001), 'Nonviolent Struggle in Kosovo', War Resisters International, available online at http://www.wri-irg.org/nonviolence/nvse16-en.htm (accessed 23 January 2016).

Climo, T. A. and Howells, P. G. A. (1976), 'Possible Worlds in Historical Explanation', History and Theory, 5: I-20.

Cohen, D. and Nisbett R. E. (1994), 'Self-Protection and the Culture of Honor: Explaining Southern Violence', Personality and Social Psychology Bulletin, 20: 551-67.

Cohen, S. (2001), States of Denial: Knowing about Atrocities and Suffering. Blackwell Publishers. Duffield, M. (2001), Global Governance and the New Wars. Zed Books.

Eckstein, H. (1975), 'Case Study and Theory in Political Science', in F. I. Greenstein and N. W. Polsby, eds, Handbook of Political Science, 94-137. Addison-Wesley.

EUROSTAT (2016), available online at http://ec.europa.eu/eurostat (accessed 16 May 2016).

Färnsveden, U., Qosaj-Mustafa, A. and Farnsworth, N. (2014), 'Profili gjinor i vendit - analizë e dalimeve gjinore në të gjitha nivelet e Kosovës', Agjencia për barazi gjinore, April: 1-16.

Farnsworth, N. (2008), Hulumtim kërkimor mbi nivelin e Dhunës në Baza Gjinore në Kosovë dhe ndikimin e tij në Shëndetin Riprodhues të Grave. Rrjeti $i$ Grupeve të Grave të Kosovës, 17-22.

Fearton, J. D. (1991), 'Counterfactuals and Hypothesis Testing in Political Science', World Politics, 43: 169-95.

Ferguson, N. (2011), Virtual History: Alternatives and Counterfactuals. Penguin.

Gastil, R. D. (1971), 'Homicide and a Regional Subculture of Violence', American Sociological Review, 36: 412-27.

Gold, M. (1958), 'Suicide, Homicide, and the Socialization of Aggression', American Journal of Sociology, 63: 651-61.

Geneva Declaration (2011), Global Burden of Armed Violence 2011. Geneva Declaration on Armed Violence and Development.

Ghobarah, H. A., Huth, P. and Russett, B. (2003), 'Civil Wars Kill and Maim People Long after the Shooting Stops’, American Political Science Review, 97: 189-202.

Giatzidis, E. (2007), 'The Challenge of Organized Crime in the Balkans and the Political and Economic Implications', Journal of Communist Studies and Transition Politics, 23: $327-51$.

GJecov, S. (1989), The Code of Lekë Dukagjini. Trans. Leonard Fox. Gjonlekaj Publishing Company.

Hagan, J., Kaiser, J. and Hanson, A. (2015), Iraq and the Crimes of Aggressive War. Cambridge University Press.

Henry, A. F. and Short, J. F. Jr. (1954), Suicide and Homicide: Some Economic, Sociological and Psychological Aspects of Aggression. Arno Press.

Holinger, P. C. and Klemen, E. H. (1982), 'Violent Deaths in the United States, 19001975: Relationships between Suicide, Homicide and Accidental Deaths', Social Science $\mathcal{E}$ Medicine, 16: 1929-38. 
Holinger, P. C., Offer, D. and Ostrov, E. (1987), 'Suicide and Homicide in the United States: An Epidemiologic Study of Violent Death, Population Changes, and the Potential for Prediction', American Journal of Psychiatry, 144: 215-19.

Karstedt, S. (2006), 'Democracy, Values and Violence: Paradoxes, Tensions, and Comparative Advantages of Liberal Inclusion', Annals of the American Academy of Political and Social Science, 605: 50-81.

Karstedt, S. (2012), 'Contextualizing Mass Atrocity Crimes: The Dynamics of Extremely Violent Societies', European Journal of Criminology, 9: 499-513.

Lester, D. (1996), Patterns of Suicide and Homicide in the World. Nova Science Publishers.

Lewis, D. (1973), Counterfactuals. Cambridge University Press.

LucI, N. (2014), 'Seeking Independence: Making Nation, Memory and Manhood in Kosova', $\mathrm{PhD}$ dissertation, University of Michigan.

Luckenbill, D. F. and Doyle, D. P. (1989), 'Structural Position and Violence: Developing a Cultural Explanation', Criminology, 27: 801-18.

Malcolm, N. (1998), Kosovo: A Short History. New York University Press.

Mangalakova, T. (2004), The Kanun in Present Day Albania, Kosovo and Montenegro. International Centre for Minority Studies and Intercultural Relations.

Marsavelski, A., Sheremeti, F. and Braithwaite, J. (2016), 'Did Nonviolent Resistance in Kosovo Fail?’ RegNet SSRN Working Paper, available online at http://papers.ssrn.com/ sol3/papers.cfm?abstract_id=2804900.

Naimark, N. M. (2002), Fires of Hatred: Ethnic Cleansing in Twentieth-Century Europe. Harvard University Press.

Pepinsky, H. (1999), 'Empathy Works, Obedience Doesn't', Criminal Justice Policy Review, 9: 141-67.

Phillips, D. L. (2012), Liberating Kosovo: Coercive Diplomacy and US Intervention. Massachusetts Institute of Technology Press.

Pozhidaev, D. and Andzhelich, R. (2005), Beating Swords into Plowshares: Reintegration of Former Combatants in Kosovo. Center for Political and Social Research.

Proksik, J. J. (2013), 'Organized Crime and the Dilemmas of Democratic Peace-Building in Kosovo', International Peacekeeping, 20: 280-98.

Pratt, S. (2013), 'Gjakmarrja: Albanian Blood Feud and Restorative Applications of Traditional Law', Available online at https://www.academia.edu/4654081/Gjakmarrja_Albanian_ Blood_Feuds_and_Restorative_Applications_of_Traditional_Justice (accessed 24 June 2016).

Quinney, R. (1965), 'Suicide, Homicide, and Economic Development', Social Forces, 43: 401-6.

RAfter, N. (2016), The Crime of all Crimes: Toward a Criminology of Genocide. NYU Press.

Republički zavod za statistiku Srbije (2007), Demografska statistika: 2004. Republički zavod za statistiku Srbije.

Republika e Kosovës (2015), Vjetari Statistikor i Republikës së Kosovës. Agjencia e Statistikave të Kosovës.

Retzinger, S. and Scheff, T. J. (1996), 'Strategy for Community Conferences: Emotions and Social Bonds', in B. Galaway and J. Hudson, eds., Restorative Justice: International Perspectives, 315-36. Criminal Justice Press.

Rich, J. A. and Grey, C. M. (2005), 'Pathways to Recurrent Trauma among Young Black Men: Traumatic Stress, Substance Use, and the Code of the Street', American Journal of Public Health, 95: 816-24. 
Salinu, I. (1982), 'Ubistva u Socijalističkoj Autonomnoj Pokrajini Kosovo', doktorska disertacija, Pravna Fakulteta, Ljubljana, Slovenia.

SAP Kosovo (1976), Statistički godišnjak SAP Kosova. Pokrajinski zavod za statistiku. SAP Kosovo (1981), Statistički godišnjak SAP Kosova. Pokrajinski zavod za statistiku. SAP Kosovo (1985), Statistički godišnjak SAP Kosova. Pokrajinski zavod za statistiku. SAP Kosovo (1989), Statistički godišnjak SAP Kosova. Pokrajinski zavod za statistiku.

SEESAC (2006), SALW Survey of Kosovo. South Eastern and Eastern Europe Clearinghouse for the Control of Small Arms and Light Weapons.

Shaw, M. (2015), War and Genocide: Organised Killing in Modern Society. John Wiley \& Sons.

Shearing, C. (1997), Violence and the Changing Face of Governance: Privatization and Its Implications. Community Peace Foundation.

SR Jugoslavija (1992), Demografska statistika 1990. Savezni zavod za statistiku.

Stephan, M. J. (2006), 'Fighting for Statehood: The Role of Civilian-Based Resistance in the East Timorese, Palestinian and Kosovo Albanian Self-Determination Movements', Fletcher Journal of World Affairs, 30: 57-79.

Stewart, E. A. and Simons, R. L. (2010), 'Race, Code of the Street, and Violent Delinquency: A Multilevel Investigation of Neighborhood Street Culture and Individual Norms of Violence', Criminology, 48: 569-605.

Sudetic, C. (1990), 'Pristina Journal: Albanians' New Way: Feuds without Blood', New York Times, 7 April.

UNODC (2016), available online at https://data.unodc.org/sys/rpt? reportfile= crimestatistics-homicide-count-data\&region=_all\&region_label=all\&subregion= _all\&subregion__label=all\&country=292\&country__label=Kosovo+\%28in\%20compliance\%20with\%20UN\%20Security\%20Council\%20Resolution\%201244\%2F99\%29\&form at=html\&fullscreen=true\&showtoc=true\#state:0 (accessed 24 June 2016).

Van Ness, D. (1986), Crime and Its Victims: What We Can Do? Intervarsity Press.

Voell, S. (2003), 'Kanun in the City: Albanian Customary Law as a Habitus and Its Persistence in the Suburb of Tirana, Bathore', Anthropos, 98: 85-101.

Walklate, S. and McGarry R., eds, (2015), Criminology and War: Transgressing the Borders. Taylor and Francis.

Weber, M., (1949), 'Objective Possibility and Adequate Causation in Historical Explanation', in E. A. Shils and H. A. Finch, eds, The Methodology of the Social Sciences, 164-88. Free Press.

Wolfgang, M. E. and Ferracuti, F. (1967), The Subculture of Violence: Towards an Integrated Theory of Criminology. Tavistock.

World Bank (2016), available online at http://databank.worldbank.org/data/reports.aspx?s ource $=2 \&$ country $=\&$ series $=$ vc.ihr.psrc.p5\&period $=\#$ (accessed 24 June 2016). 